\title{
飲食店向け不動産営業を支援する 申込み顧客推薦モデルの提案
}

\section{Customer Recommendation Model to Support Real Estate Salespersons for a Restaurant}

\begin{tabular}{|c|c|}
\hline $\begin{array}{l}\text { 河村 一輝 } \\
\text { Kazuki Kawamura }\end{array}$ & $\begin{array}{l}\text { 奈良先端科学技術大学院大学 } \\
\text { Nara Institute of Science and Technology } \\
\text { kawamura.kazuki.ka3@is.naist.jp }\end{array}$ \\
\hline 諏訪 博彦 & 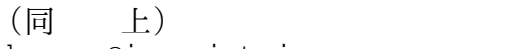 \\
\hline Hirohiko Suwa & h-suwa@is.naist.jp \\
\hline 小川 祐樹 & 立命館大学 \\
\hline Yuki Ogawa & $\begin{array}{l}\text { Ritsumeikan University } \\
y \text {-ogawa@ fc.ritsumei.ac.jp }\end{array}$ \\
\hline 荒川 豊 & 奈良先端科学技術大学院大学 \\
\hline Yutaka Arakawa & $\begin{array}{l}\text { Nara Institute of Science and Technology } \\
\text { ara@is.naist.jp }\end{array}$ \\
\hline 安本 慶一 & 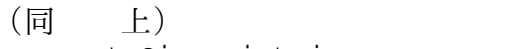 \\
\hline Keiichi Yasumoto & yasumoto@is.naist.jp \\
\hline 太田 敏澄 & 行政情報システム研究所 \\
\hline Toshizumi Ohta & $\begin{array}{l}\text { The Institute of Administrative Information Systems } \\
\text { tohta@aqua.ocn. ne. jp }\end{array}$ \\
\hline
\end{tabular}

keywords: machine learning, recommendation, sales support model

\section{Summary}

In this paper, we propose a recommendation model of application customer to reduce the time and cost of the salesperson by recommending the application customer to salesperson. The model is built based on customer information, premise information, and two new features which are extracted from salesperson's feedback. Estimation precision is evaluated by three algorithms: SVM, Decision Tree and Random Forest. We applied three algorithm against five data sets. As a result, the highest estimation precision was $49.2 \%$ using RF against the data which selected by some important features (data 5). In the case of using the customer information and property information (data 3), estimation precision was $38.7 \%$. Moreover in the case of adding new two features against that data (data 4), estimate precision was $44.2 \%$. From comparison between data 3 and data 4 , we clarified that the new two features increased the estimation precision. Also, from comparison between data 4 and data 5, we clarified that selecting some important features increased the estimation precision. In addition, according to the feedback from the ABC TENPO Inc which we are conducting joint research, our model increased the precision compared with the veteran salesperson.

\section{1.はじめに}

近年，WWW の発展によりその情報構造やアクセス方 法も劇的に変化している．例えば, Web 上の情報リソー スに効率的にアクセスするためのデータベース技術の普 及により，様々な企業において顧客情報が容易に収集で きるようになってきた。 さらに，人工知能に代表される 知的情報処理技術の発展により，蓄積データの処理技術 も多様化してきている．それに伴い，多くの中小企業が 顧客情報を収集し，様々な営業活動に活用しようと試み ている.しかしながら，どのような事例に対して，どの
ような情報を収集し，いかに処理すべきかという知見の 蓄積は，まだまだ不十分である。

本研究では活用事例の蓄積の一つとして, 飲食店向け 不動産企業の営業支援を行うことを目指す。具体的な営 業支援としては，申込みをする顧客（以下，申込み顧客） を営業マンに自動で予測し推薦する仕組みを提案する. 申込み顧客を自動で予測することで, 営業マンの顧客探 索コストを削減するとともに，申込み確率の低い顧客に 対する営業コストを削減できる。では，どのような特徵 量をもつデータを収集し，どのような情報処理技術を用 いることで，効率よく申込み顧客を抽出できるのであろ 
うか. 本稿では, 効率よく申込み顧客を抽出するための データ特徴量および情報処理手法を明らかにする。

具体的な研究対象として, 飲食店向け不動産会社であ る（株） $\mathrm{ABC}$ 店舗 $* 1$ から協力を得た， ABC 店舗は，主に 居抜き物件の仲介を通して飲食店の開業や売却をサポー トしている不動産会社である. ABC 店舗への聴き取り調 査によれば，飲食店の起業を目指す顧客が物件申込みに 至る流れは，1）検索サイトへの登録，2）検索サイト での物件探索，3）気になった物件の内見，4）気に入っ た物件への申込みとなる。

対象顧客は，飲食店を開業することが初めての顧客が 多く, 適切な探索条件や決定条件を把握していないケー スが多い，例えば，申込み顧客は，理想とする地域や立地 に基づいて探索を行うが，その探索条件は有名地域（恵 比寿・銀座など）や好立地（駅近，路面店など）となり， 自ずと賃料などのコストが高くなりやすく，申込み顧客 の実態（開店資金など）との不整合が起こる。また，顧 客の収入に応じて賃料の上限をおおよそ設定できる住宅 用物件と異なり，飲食店向け物件ではその物件の条件に より売上規模が大きく変化するため賃料のみに基づく意 思決定はできず，顧客は物件探索や申込みに悩むことと なる.

ここで重要となるのが営業マンの存在である. ABC 店 舗では，営業マンが内見や申込みをしそうな顧客を探索 し，営業活動を行うことで申込みを促している．営業マ ンは長年の勘と経験によって，数ある内見をした顧客リ スト（内見顧客）から，より成約に至るであろう顧客を 探索し，電話やメールによる営業活動を行っている。こ れにより，顧客は自分にあった物件への申込みに到達し ている.

しかし，この方法は営業マンに多大な探索コストを強 いることになる．営業マンは，内見時に顧客とコミュニ ケーションを行い, 顧客の希望や満足/不満足点を把握し ようと試みている。 また，それに加えて，検索サイトへ の登録時の情報や，これまでの検索サイトでの物件探索 ログを閲覧し，その結果に基づいて営業活動を行う顧客 を選定している，そのため，顧客の選定のために，多大 な時間を必要とすることになる，さらに，営業マンはこ の探索作業を各々の勘と経験に基づいて行っているため, 新人営業マンがこの探索作業を効率よく実施することは 困難である。

探索コストの削減手法の一つとして，探索を実施せず すべての顧客に営業を実施する手法も考えられる。しか し，顧客の嗜好に合わない物件の推薦は顧客の満足度を 下げることになるのに加えて，顧客である開店希望者の 多くは飲食店従業員である割合が高く，現在の雇用者に 物件探索の実態を知られたくないなどの事情があり，頻 繁な営業は控えなければならない.そのため，営業支援 のためには，顧客の購買行動を予測し，効率よく物件を

*1 http://www.abc-tenpo.com/
推薦する申込み顧客推薦手法が必要である.

顧客の購買行動を予測し商品を推薦する代表例として は，推薦システムがある. 主な推薦手法として, 協調フィ ルタリングやコンテンツフィルタリングがある。これら の手法は多くの適用事例があり, Amazon や転職サイト 「キャリアトレック」などで利用されている。これらは, 同じ商品を多くの人が購入できることや，比較的安価で 同じ人が複数の商品を購入できることを前提としている ため, 特徵情報の抽出が可能になっている. しかし, 本研 究が対象とする商品は飲食店向け不動産店舗であるため, 基本的に世の中に 2 つして同じ商品は存在しない。 ま た，複数の不動産を取得するには多額な費用が必要とな るため，同一人物が複数回購入することを前提にできな い. そのため, 従来の推薦手法で多く使われる協調フィ ルタリングやコンテンツフィルタリングのように, 購買 履歴から嗜好を生成することや，その嗜好傾向の類似性 から商品を推薦することができず，新たな手法を検討す る必要がある.

そこで我々は, 機械学習を用いて顧客の購買行動を予 測する手法に注目する，機械学習は，収集されたデータ に基づいて, 人間が行っている学習と同様の機能をコン ピュータで実現しようとする手法であり，営業活動支援 にも活用され始めている [Yiqing 15]. 本研究では, 飲食 店向け不動産企業の営業マンに着目し, 彼らが学習して いることをコンピュータに学習させ，その学習結果を営 業活動支援に役立てることを目指す。

まず，営業マンが最も重要視している内見時の顧客情報 と物件情報に基づいて申込み顧客推薦モデルの構築を行っ た。モデル構築アルゴリズムとしては, SVM (Support Vector Machines）, 決定木, RF（Random Forest）を比 較した。その結果, 顧客情報および物件情報に対して RF を用いた場合の適合率は $38.7 \%$ であた。その結果を営 業マンにフィードバックし検討を行った結果，新たな特 徵量として顧客の開店意欲および物件所在地の地域ポテ ンシャルが申込み行動に影響を及ぼすとの回答が得られ たため，モデルの改良を行った。その結果， $49.2 \%$ 適 合率で申込み顧客を推葴することができた。共同研究先 である $\mathrm{ABC}$ 店舗からのフィードバックによるとベテラ ンの営業マンでも 2-3 割程度の精度であり, 本手法は営 業効率をあげることに大いに貢献できるとの評価が得ら れた。

\section{2. 関 連 研 究}

本章では, 関連研究として従来の推薦手法および機械 学習を用いた営業支援に関する研究について述べる.

\section{$2 \cdot 1$ 既存の推薦手法}

代表的な推薦手法として, 協調フィルタリングやコン テンツフィルタリングが提案されている[Adomavicius 
05, 神嶌 06, 神嶌 08]. 協調フィルタリングは, ユーザの 嗜好を評価履歴という情報として蓄積し, 評価対象ユー ザと似た評価履歴を持っているユーザの評価履歴をもと にユーザの嗜好を推定し, 推薦対象となる商品やサービ スを推薦する手法である [土方 04, 神嶌 06, Mooney 99,

Pazzani 96].

コンテンツフィルタリングは, 推薦対象の特徵情報と ユーザの評価履歴から抽出した特徵情報を比較し, それら が類似する商品やサービスを推薦する手法である [Resnick 94, Resnick 99]. これらの手法は, 様々な応用研究がな されており, 実社会でも多く使われている有益な手法で ある [J.Ben 01, Saeideh 14].

しかしながら, 本研究が対象とする不動産物件では, 購買頻度が極端に少ないため特徵情報の収集が困難, 他 者と同じ商品を購入することができない, 対象顧客が自 分にふさわしい物件を把握できていないなどの理由から, 本研究への適応は困難である. そこで我々は機械学習に 着目する.

\section{$2 \cdot 2$ 機械学習を用いた営業支援}

機械学習を営業支援に活用する試みは進んでいる. Yiqing ら [Yiqing 15] は, 中国の携帯会社のデータを使い, プリ ペイド携帯の解約者を予測し，その解約者に電話営業を 行うよう促しプリペイド解約を思いとどまらせる手法を 提案している. プリペイド携帯の解約者を予測し, 営業 マンに電話をかけさせることで解約を思い留まらせる仕 組みである. ユーザの行動ログ，メッセージログ，パケッ 卜, 通話の品質等から解約する確率の高いユーザを推定 している.

EverString では, B2B の企業に対して, 商品を買って くれそうな顧客を推䳸するサービスを行っている．従業 員規模, 収益状況, 経営者の経歴, 地域などを説明変数 に用いて, 成約確度の高いもしくは低い顧客を判定する モデルを機械学習で構築している.

機械学習を不動産営業支援に用いようとする研究も存 在する. Fu ら [Fu 14] の研究では, dianping.comのレイ ティングやチェックイン情報等のオンラインの情報とタ クシーやバスのトラッキングなどのオフライン情報から 機械学習を行い, 中国の不動産価格の推定を行っている. ここでは, チェックインの回数や物件ごとのレイティン グが高い場所が不動産の価格推定において大きな重要度 を示すことを明らかにしている。

$\mathrm{Wu}$ ら [Wu 09] の研究では, 物件の面積や築年数といっ た物件情報だけでなく風水の属性を入れたデータセット を用いて不動産の価格推定を行っている. 全体を通して の価格推定の重要度は物件の延べ床面積が一番高いこと を明らかにしている. また, 風水の属性を含めたデータ セットは, 風水の属性を除いたデータセットと比べてよ り高い精度を出すことができ, 風水の属性が重要である ことを明らかにしている。
これらの研究からわかることは, どのような情報処理 技術を使うかということもさることながら，どのような 特徵量を用いるかが重要であるということである。例え ば, Yiqing ら [Yiqing 15] は, 単純に収集した変数を使用 するのみならず, 変数同士の組み合わせを特徵量として 用いることで, 解約者の予測精度向上を試みている。 ま た, $\mathrm{Wu} ら$ [ Wu 09] は, 台湾という土地柄を考慮し風水 という特徴量を入れることで不動産価格推定の精度向上 を図っている. 本研究においても, どのような特徵量が 精度向上に寄与するのかに着目し検討を進めることが重 要となる.

本研究の貢献は, 特徵量を抽出・選択する方法を実際 の営業支援に基づいて提案・検証していることである．営 業支援を考える場合, 最初から適した特徵量がそろって いることはほとんどなく, 多くの特徴量の中から抽出す る必要がある．また，場合によっては既存の変数を組み 合わせたり, 新たにデータを取得したりする必要がある. 先行研究においては, Yiqing らは既存の多くの変数を組 み合わせて新たな変数を作り出しており, $\mathrm{Wu} ら$ ら台湾 という土地柄を考慮したモデルに基づいて風水という変 数を新たに付加している.これに対して本研究では, 従 業員の暗䓡知に着目し, 従業員の暗黙知を 2 回の聴き取 り調査に基づいて形式知化（変数化）することで, 特徵 量の抽出を行っている. 加えて, 抽出された特徵量に対 して実践的なアルゴリズムおよび特徵量セットの選定方 法を提示している.この一連の手続きを実事例に基づい て検証することは，機械学習を営業支援で利用する場合 における特徴量の抽出・選択手法の知見を提示すること になり, 社会的に意義がある.

\section{3. 申込み顧客推薦モデルの構築}

本章では, 構築した申込み顧客推薦モデルについて述 ベる.

\section{$3 \cdot 1$ 提案モデルの概要}

図 1 は, 既存の営業手法と提案手法を示している. 既 存手法において, 営業マンは手作業で大量の内見顧客の 中から申込み顧客の発掘を行い, 電話営業を行っている. そのために, 時間と労力が必要であり, コストがかかっ ている. また, 営業の成功確率は, 営業マンの勘と経験 から導き出されるノウハウ（暗黙知）により変化し，聴 き取り調査よりベテラン営業マンでも 2-3 割程度である ことが確認されている。ノウハウ（暗黙知）を形成でき ていない新人営業マンは, より低確率であり営業機会を 損失している. そこで, 提案手法では暗黙知であるノウ ハウを機械学習によりモデル化する.

モデル化のために, ベテラン営業マンが何に着目して 顧客の選定を行っているのか聴き取り調査を行い, 調査 により抽出された特徵量に用いて機械学習により申込み 
顧客推萀モデルを構築する，本モデルでは，申込み顧客 推薦モデルに基づいて申込顧客リストを作成し電話営業 を促すことで, 営業マンの労力を削減し, 効率的な営業 を支援する。

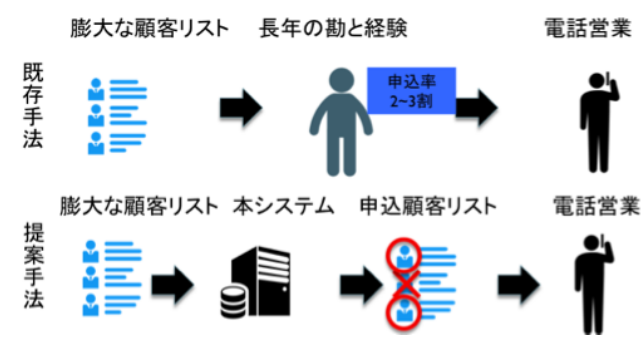

図 1 既存手法と提案手法の違い

\section{$3 \cdot 2$ モデル構築のためのデータセット}

聴き取り調査の結果，モデル構築のための初期特徵量 として，2つの特徵量群（顧客情報, 物件情報）が確認さ れた (図 2).この調査の目的は, 基本モデル構築のための 初期特徵量の抽出である. 具体的には, どのように営業 活動をしていますか，どのような点に着目して申込み顧 客の推定をしていますかなどをインタビュー形式で質問 している. 営業マンからは，内見時の顧客の様子で判断 している，物件により差があるなどの回答が得られたた め, 内見時の顧客のどんな様子に着目しているのか, 物 件の差異を判断する要因は何かをさらに確認している.

また，聴き取り調査に基づいて構築したモデルによる 予測結果を $\mathrm{ABC}$ 店舗へフィードバックし，再度聴き取 り調査を行った結果，フィードバックに基づく特徵量と して新たに $2 つ の$ 特徵量群（開店意欲, 地域ポテンシャ ル）が抽出された。この調査の目的は，基本モデルでは 抽出されなかった営業マンが気づきにくい特徵量を抽出 することである．推定結果の全体傾向を説明した後，正 しく推定できた事例とできなかった事例を提示すること で, 営業マンに初期特徵量以外の検討を促している.

具体的には，初期特徵量は同じであるにもかかわらず， 申込みした顧客と申込みしなかった顧客を提示し，これ らの顧客の申込みの有無を推定可能か，可能であるなら ばどのような視点で推定するのかさらに質問を行ってい る。営業マンからは，熱意のある顧客とそうでない顧客 がいる，人気エリアがあるなどの回答が得られたため，そ れらの差異を抽出するにはどんな点に着目すればよいか 確認を行い特徵量としている。このように，具体的な場 面を営業マンにフィードバックすることにより，初期特 徵量としては言語化できなかった新たな特徵量を抽出し ている. 各特徵量群について説明する (表 1).

\section{$\S 1$ 顧客情報}

1 つ目の特徵量群は，内見時の顧客情報である．聴き 取り調査によれば，営業マンは内見時の顧客の様子から，

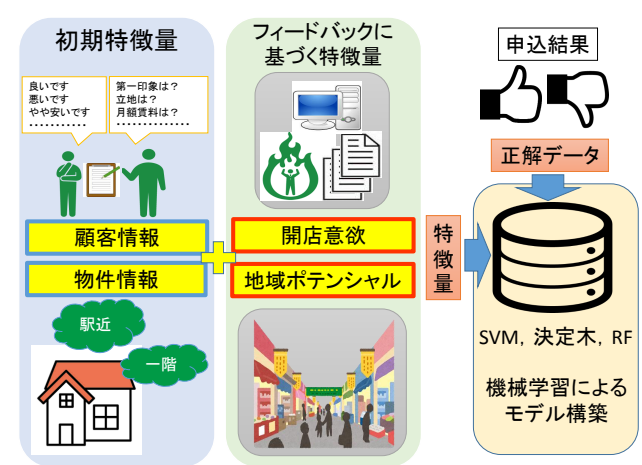

図 2 モデル構築のための特徵量

表 1 特徴量一覧

\begin{tabular}{|c|c|c|c|}
\hline 種別 & 項目 * & & 説明 \\
\hline \multirow{6}{*}{$\begin{array}{l}\text { 顧 } \\
\text { 情 } \\
\text { 報 }\end{array}$} & 第一印象 & (4) & \multirow{6}{*}{$\begin{array}{l}\text { - 第一印象から取得総額の5項目は, 物件に対 } \\
\text { する印象を5段階評価のアンケートで取得. } \\
\text { ・ 最初の2項目は, 良い一悪い } \\
\text { ・ 残りの3項目は, 安い一高い. } \\
\text { - 事前調査は, 物件や地域のことを知っていた } \\
\text { かについて3段階のアンケート. }\end{array}$} \\
\hline & 立地 & (5) & \\
\hline & 月額賃料 & (9) & \\
\hline & 譲渡価格 & (10) & \\
\hline & 取得総額 & (11) & \\
\hline & 事前調査 & (12) & \\
\hline \multirow{5}{*}{$\begin{array}{l}\text { 物 } \\
\text { 件 } \\
\text { 情 } \\
\text { 報 }\end{array}$} & 月額賃料 & (2) & \multirow{5}{*}{$\begin{array}{l}\text { - 月額賃料, 床面積は実数. } \\
\text { ・ 駅徒步は駅からの時間(分). } \\
\text { ・ 階数は何階であるか. } 1 \text { 階を基準とし, 地下1 } \\
\text { 階と地上2階を同等としいる. } \\
\text { ・ 居抜きは居抜き物件であるか }(1,0) \text { で判定. }\end{array}$} \\
\hline & 床面積 & (3) & \\
\hline & 駅徒歩 & (7) & \\
\hline & 階数 & (13) & \\
\hline & 居抜き & (14) & \\
\hline \multirow{3}{*}{ 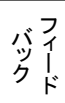 } & 開店意欲(量) & (6) & \multirow{3}{*}{$\begin{array}{l}\text { - 開店意欲(量)/(期間)は, 内見日までの過去 } \\
\text { 2週間での総アクセス数/総日数 } \\
\text { ・ 最寄駅の単位面積当たりの平均賃料 }\end{array}$} \\
\hline & 開店意欲(期間) & (8) & \\
\hline & 地域ポテンシャル & (1) & \\
\hline
\end{tabular}

申込みの有無についておおよその判断をしていることが 確認された。具体的に，内見時の顧客の反応としてどの ようなところに注目しているかを確認したところ，顧客 の言葉として「立地」「賃料」という言葉が出てきた時や, 物件や地域について事前知識があるか（事前に調べてい るか）どうか分かった時に申込みの有無が判断しやすい とのコメントが得られた。そこで, 内見時に顧客にアン ケートを答えてもらいデータを収集し，特徴量とするこ ととした。

アンケートでは, 第一印象, 立地条件, 月額賃料, 譲渡価 格, 取得総額について顧客がどう感じているかと事前調 査の有無について確認している．顧客の物件に対する主 観評価が，申込み行動に影響を及ぼすと考え，これらを 特徵量に含めることとした。

\section{$\S 2$ 物件情報}

2 つ目の特徵量群は, 物件情報である. 聴き取り調査 によれば，営業マンは物件の条件から，申込み顧客の有 無をある程度予想していることが確認された。そこで，各 物件が保持している物件情報を特徴量にすることとした. 物件情報は多種多様であるが，聴き取り調査により重要 であると指摘された月額賃料, 面積, 何階か, 最寄駅か ら徒歩何分か，居抜き物件かどうかの 5 つを選定した。 
$\mathrm{ABC}$ 店舗が扱う物件は多種多様であり, 物件立地や価 格などの物件自体の特徵により, 人気・不人気が存在す る.このことから, 物件自体の特徵が顧客の申込み行動 に影響を及ぼすと考え, これらを特徵量に含めることと した.

\section{$\S 3$ フィードバックに基づく特徵量}

前述の二つの特徵量群に基づいて構築したモデルによ る予測結果 (後述) を営業マンにフィードバックし, 再 度聴き取り調査を行った。 その結果, 新たに 2 つの特徵 量群が抽出された。

フィードバックに基づく聴き取り調査によれば，申込 みに至るかどうかは, 顧客の開店意欲により大きく左右 され，それらは検索サイトでの探索行動により推測でき るとの回答が得られた。 そこで我々は, 内見に至る直前の 行動に着目し, 顧客の開店意欲を測るための二つの特徵 量を定義した。一つ目の特徵量は, より意欲の高い顧客 は様々な物件の探索を行うという仮定のもと, 内見日ま での過去 2 週間での総アクセス数を開店意欲（量）と定 義した.もう一つの特徵量は, より意欲の高い顧客は継 続して探索を行うという仮定のもと内見日までの過去 2 週間での総アクセス日数を開店意欲（期間）と定義した。

また, 同じような物件情報（面積, 賃料, 路面店かど うかなど）であっても, 存在する地域の人気度により申 込みに至るかどうかが変化するとの回答が得られた。そ こで, 我々は各地域が持つ人気度に着目し, 地域ポテン シャルを測るための特徵量を定義した。この特徵量は, よ り人気がある地域の賃料は高いという仮定のもと, 最寄 駅毎の単位面積当たりの平均賃料を地域ポテンシャルと 定義した。

\section{$3 \cdot 3$ モデル構築のための学習アルゴリズム}

前述の特徵量に基づいて, 機械学習により申込み顧客 推薦モデルを構築する. モデルの構築には, データマイ ニングッールである Weka[Weka] を用いた. Weka は多 数の機械学習アルゴリズムに基づく分類器を実装して おり, 本研究では, 代表的な機械学習アルゴリズムであ る SVM (Support Vector Machines : サポートベクターマ シン)[Cristianini 00], 決定木 (C4.5) [Quinlan 96], RF (Random Forests) [Breiman 01] の 3 つの手法を用いて 特徵量の各組み合わせに対して申込み顧客推薦モデルを 構築する。

(1) SVM (Support Vector Machines)

SVM は, 代表的なパターン認識器の一つであり, データ分類の学習アルゴリズムの中で高い汎化能力を 持つことが知られている. 各データ点との距離（マー ジン）が最大となる分離平面を求めることでデータ を線形分離する.また, データが非線形の場合でも, カーネルトリックによって入力空間をより高次の特 徵空間に写像することで, その上で線形分離を行う ことができる。
(2) 決定木

決定木 (decision tree) は, 属性值の条件によりノー ドを分岐させて木構造の分類器を生成する伝統的な 機械学習手法の 1 つである. 決定木学習の特徵とし て, if-then ルールに基づいて木を生成していくため, 他の手法と比べて分類過程の可読性が高いという利 点がある. 本研究では, 決定木学習の代表的なアル ゴリズムである C4.5 決定木を用いた。

(3) RF (Random Forests)

$\mathrm{RF}$ はアンサンブル学習を用いた機械学習アルゴリズ ムの 1 つである. 複数の決定木を弱分類器として使 用し，その結果を統合して結果を得る. 他の分類器 に比べ性能が高く，判定速度も高いと言われている.

\section{4. 評 価 実 験}

本章では, 実験概要および実験結果について述べる.

\section{$4 \cdot 1$ 実 験 概 要}

提案手法で示したデータから申込み推定モデルについ て検証するために，実際にデータを収集して評価実験を 行った。収集データは，2014 年 2 月 3 日から 7 月 10 日 までに内見を行った計 1132 件である. $3 \cdot 2$ 節で示したと おり, 顧客情報として, 第一印象, 立地条件, 月額賃料, 譲 渡価格, 取得総額に関する顧客の感想を 5 段階評価で取得 し, 事前調査の有無を 3 段階で取得している. 取得方法 は, 顧客が物件を内見した後に構造化インタビュー形式 で不動産会社の営業の方が実施している. 物件情報とし ては, 月額賃料, 面積, 何階か, 駅徒歩, 居抜きの 5 項目 について, $\mathrm{ABC}$ 店舗のデータベースから取得している.

また，フィードバックに基づく特徵量として追加した 開店意欲, および地域ポテンシャルについては, 3.3 節で 示した方法を用いて, $\mathrm{ABC}$ 店舗のデータベースから取得 している.

評価には, 10 交差検証法を用いた．教師データを 10 分割し, その 1 つをテストデータとして評価し, それを 10 回繰り返すことで全体を評価している。これにより, 過学習や汎化誤差に配慮している.

評価指標としては，申込むと推定した場合の適合率を 用いた．評価に申込むと推定した場合の適合率を用いる 理由は, 申込まなかった顧客への営業を減らしたいから である. 申込まない顧客に営業することは，営業マンに とって高コストであるだけでなく，顧客の嗜好に合わな い物件の推薦は顧客の満足度を下げることになる．また， 顧客である開店希望者の多くは飲食店従業員である割合 が高く, 現在の雇用者に物件探索の実態を知られたくな いなどの事情があり，頻繁な営業は控えなければならな いことも理由のひとつである.

評価は, 3.4 節で示した 3 種類のアルゴリズム（SVM, 決定木，RF）に対して，5種類のデータを用いて, 計 15 
個のモデルを比較している． 5 種類のデータは，以下の とおりである. なお, (5) の重要な特徵量の抽出は, ジニ 係数の平均減少量 (mean decrease gini) を用いて行って いる.

（1）顧客情報（データ 1）

（2）物件情報（データ 2)

（3）顧客情報十物件情報（データ 3）

（4）顧客情報+物件情報+フィードバックに基づく特 徵量（データ 4)

（5）重要な特徵量に絞り込んだデータ（データ 5)

\section{$4 \cdot 2$ 実 験 結 果}

はじめにアルゴリズムごとの適合率の比較を行い，そ の後, 特徵量の違いによる比較を行う。

\section{$\S 1$ アルゴリズムの性能評価}

表 2 は，15 の組み合わせの評価結果である．顧客情報 のみを使ったデータ 1 で比較すると，SVM を用いた場 合が 31.9\%（表 3），決定木を用いた場合が 27.6\%（表 4），RF を用いた場合が $34.0 \%$ （表 5）と，RF を用いた 場合がもっとも良い結果となっている。

表 2 データとアルゴリズムの組み合わせによる評価結果

\begin{tabular}{|c|c|c|c|c|c|}
\hline & 1 & 2 & 3 & 4 & 5 \\
\hline SVM & $31.9 \%$ & $20.4 \%$ & $35.1 \%$ & $28.4 \%$ & $26.1 \%$ \\
\hline 決定木 & $27.6 \%$ & $0 \%$ & $29.3 \%$ & $29.7 \%$ & $40.3 \%$ \\
\hline RF & $34.0 \%$ & $21.3 \%$ & $38.7 \%$ & $44.2 \%$ & $49.2 \%$ \\
\hline
\end{tabular}

表 3 は，データ 1 に対して SVM を用いて申込み顧客 を推定した結果である。申込みをすると推定した 116 人 中，実際に申込みをした人数は 37 人であり，31.9\%の適 合率で推定している.

表 4 は，データ 1 に対して決定木を用いて申込み顧客 を推定した結果である。申込みをすると推定した 76 人 中，実際に申込みをした人数は 21 人であり，27.6\%の適 合率で推定している

表 5 は，データ 1 に対して RFを用いて申込み顧客を 推定した結果である.申込みをすると推定した 100 人中， 実際に申込みをした人数は 34 人であり， $34.0 \%$ 適合率 で推定している.

表 3 SVM ×データ 1 の結果

\begin{tabular}{|c|c|c|}
\hline & 申込まない & 申込む \\
\hline 申込みしてない & 888 & 79 \\
\hline 申込みした & 128 & 37 \\
\hline 適合率 & & $31.9 \%$ \\
\hline
\end{tabular}

同様に，データ 2-5に対して比較した結果，すべての データに対して，RFの適合率がもっとも良い結果となっ ていることが確認された。このため，特徵量（データセッ
表 4 決定木×データ 1 の結果

\begin{tabular}{|c|c|c|}
\hline & 申込まない & 申込む \\
\hline 申込みしてない & 912 & 55 \\
\hline 申込みした & 144 & 21 \\
\hline 適合率 & & $27.6 \%$ \\
\hline
\end{tabular}

表 $5 \mathrm{RF} \times$ データ 1 の結果

\begin{tabular}{|c|c|c|}
\hline & 申込まない & 申込む \\
\hline 申込みしてない & 901 & 66 \\
\hline 申込みした & 131 & 34 \\
\hline 適合率 & & $34.0 \%$ \\
\hline
\end{tabular}

ト）の違いによる分析については，主に RFを用いた場 合の結果に着目して，比較を行う。

\section{$\S 2$ 顧客情報を用いた場合}

先に説明したとおり，表 5 は，データ 1 （顧客情報） に対して RF を用いて申込み顧客を推定した結果であり, $34.0 \%$ 適合率で推定している。この適合率は, 営業マ ンの推定精度約 2-3 割という聴き取り調査の結果とほぼ 同程度である。

\section{$\S 3$ 物件情報を用いた場合}

表 6 は，データ 2 (物件情報) に対して RF を用いて 申込み顧客を推定した結果である，申込みをすると推定 した 61 人中，実際に申込みをした人数は 13 人であり， $21.3 \%$ 適合率で推定している。顧客情報のみを用いた 場合 $(34.0 \%)$ と比較して適合率が $12.7 \%$ 減少すること が確認できた。このことから物件の申込みには，物件自 体の情報よりも，顧客がどう感じたかという心理状態が 他の要素と比べて大きく影響していることが確認された.

表 6 RF ×データ 2 の結果

\begin{tabular}{|c|c|c|}
\hline & 申込まない & 申込む \\
\hline 申込みしてない & 919 & 48 \\
\hline 申込みした & 152 & 13 \\
\hline 適合率 & & $21.33 \%$ \\
\hline
\end{tabular}

\section{$\S 4$ 顧客情報と物件情報を組み合わせた場合}

表 7 は，データ 3 (顧客情報十物件情報) に対して RF を用いて申込み顧客を推定した結果である。申込みをす ると推定した 62 人中，実際に申込みをした人数は 24 人 であり，38.7\%の適合率で推定している．顧客情報のみ を用いた場合 $(34.0 \%)$ と比較して適合率が $4.7 \%$ 向上す ることが確認できた。このことから，物件情報は，申込 み顧客推定に寄与することが確認された。

\section{$\S 5$ フィードバックに基づく特徵量を追加した場合}

表 8 は, データ 4 （顧客情報十物件情報十フィードバッ クに基づく特徵量）に対して RF を用いて申込み顧客を 推定した結果である. 申込みをすると推定した 52 人中, 実際に申込みをした人数は 23 人であり, $44.2 \%$ の適合率 
表 7 RF $\times$ データ 3 の結果

\begin{tabular}{|c|c|c|}
\hline & 申込まない & 申込む \\
\hline 申込みしてない & 929 & 38 \\
\hline 申込みした & 141 & 24 \\
\hline 適合率 & & $38.7 \%$ \\
\hline
\end{tabular}

で推定している．顧客情報のみを用いた場合（34.0\%）と 比較して適合率が $10.2 \%$ ，顧客情報と物件情報を用いた 場合 $(38.7 \%)$ と比較して適合率が向上することが確認 できた。このことからフィードバックに基づく特徴量は, 申込み顧客推定に寄与することが確認された。

表 $8 \mathrm{RF} \times$ データ 4 の結果

\begin{tabular}{|c|c|c|}
\hline & 申込まない & 申込む \\
\hline 申込みしてない & 938 & 29 \\
\hline 申込みした & 142 & 23 \\
\hline 適合率 & & $44.2 \%$ \\
\hline
\end{tabular}

\section{$\S 6$ 重要な特徵量に絞り込んだ場合}

表 9 は, データ 5（重要な特徴量に絞り込んだデータ） に対して RF を用いて申込み顧客を推定した結果である. 申込みをすると推定した 59 人中，実際に申込みをした 人数は 29 人であり, $49.2 \%$ の適合率で推定している.

表 $9 \mathrm{RF} \times$ データ 5 の結果

\begin{tabular}{|c|c|c|}
\hline & 申込まない & 申込む \\
\hline 申込みしてない & 937 & 30 \\
\hline 申込みした & 136 & 29 \\
\hline 適合率 & & $49.2 \%$ \\
\hline
\end{tabular}

重要な特徵量の抽出は, ジニ係数の平均減少量 (mean decrease gini) を用いて行なった。 その結果, 重要度が上 位となったのは, 地域ポテンシャル, 月額賃料, 面積, 第 一印象, 立地条件などであり, 事前調査の有無や階数, 居 抜きなどが下位となった (表 1). そこで, 重要度の高い 特徵量から順に選択し $\mathrm{RF}$ を用いてモデルを構築した結 果，上位 9 個の特徵量を用いた場合に適合率が高くなる ことが確認できた。 RF の推定精度に基づいて重要な特 徵量を抽出している理由は, データ 1-4において常に RF を用いたモデルの精度が高かったため，RFにおいてより 推定精度の高い特徵量セットを抽出するためである。ま た，今回は同じ特徵量セットを用いた場合のアルゴリズ ム毎の精度を比較しているため, SVM/決定木について も RF の推定精度に基づく特徴量セットをデータ 5 とし て適応している.

データ 1 (顧客情報) を用いた場合（34.0\%）と比較し て適合率が $25.2 \%$ ，データ 3 (顧客情報十物件情報）を用 いた場合（38.7\%）と比較して適合率が $10.5 \%$ ，データ 4 （顧客情報十物件情報+フィードバックに基づく特徵量） を用いた場合（44.2\%）と比較しても適合率が 5.0\%向上
することが確認できた。このことから重要な特徵量の絞 込みは, 申込み顧客推定に寄与することが確認された。

\section{5. 考察}

本章では，まず，4章の結果を $\mathrm{ABC}$ 店舗へフィードバッ クしたことに基づく考察について述べる. 次に， $\mathrm{ABC}$ 店 舗との共同研究に基づいて，営業支援のためにどのよう な特徵量をもつデータを収集し，どのような情報処理技 術を用いるかについて考察する。最後に，申込み顧客推 定システムの実装について述べる.

\section{$5 \cdot 1 \mathrm{ABC}$ 店舗へのフィードバックに基づく考察}

推定結果について, データ提供企業である $\mathrm{ABC}$ 店舗 からのフィードバックも踏まえて考察を行う. $\mathrm{ABC}$ 店舗 からのフィードバックは, 推定結果の提示・説明および 質疑応答の会議形式で取得している.

15 個のモデルを比較した結果, データ 5（重要な特徴 量に絞り込んだデータ）に対して RF を用いて申込み顧 客を推定した場合に，最も効率よく申込み顧客を推定で きることが確認された。適合率は $49.2 \%$ であり，申込む と推定した顧客のうち約半分が申込みをすることになる. この結果を $\mathrm{ABC}$ 店舗に伝えたところ, 従来の営業手法で はベテランの営業マンでも 2-3 割程度の精度であり, 本 手法は営業効率化に寄与するとのコメントを得ている.

従来の営業手法とは，内見時の顧客とのコミュニケー ションに基づく希望や満足/不満足点の把握, 検索サイト 登録情報の確認, 検索サイトにおける物件探索ログの確 認などに基づく営業活動を指す。営業マンは個々に顧客 とコミュニケーションをとり，自分が必要とする情報を 取得するとともに，データベースにアクセスしている. そのため, 個々の勘と経験が要求されるとともに，デー タベースから情報を取得するコストが必要となる。これ に対して, 我々のシステムは, 個々の勘と経験を必要と せず，自動的に従来よりも高い精度で申込み顧客を抽出 できるため, 営業効率化に寄与するとの回答が得られて いる.

地域ポテンシャルや物件情報を特徵量として用いた効 果については，「良い立地の物件は申込みが殺到する．良 い物件は顧客の状況にかかわらず申込みされる」とのコ メントが得られており，分析結果と整合性が取れている. また，ジニ係数に基づいて抽出した重要な特徵量につい ても, 営業マンの感覚と一致するとの解答が得られてお り，この結果についても整合性が取れていると考える.

本研究においては，4.1 節で示したとおりの理由から 適合率に着目して評価しているが，実際の不動産営業で は営業成功数も重要となる. 本研究のモデルでは, 最も 高い適合率でも約 30 件しか推定できておらず，残りの約 1000 件の中から約 130 件の申込み顧客が予測できてい ない.そのためシステムから抽出された顧客にのみ営業 
を実施するのでは不十分であり，システムを使用するこ とにより効率化（探索時間の削減）を行いつつ，その後 営業マンによる探索をすることで網羅率を上げる戦略が 考えられる。この戦略は $\mathrm{ABC}$ 店舗からも支持されてお り, システムがない場合はすべて営業マンの勘と経験で 実施しているので，システムで抽出できない部分につい て営業マンが補うことは問題ないと同意が得られている.

\section{$5 \cdot 2$ 特徵量の選択}

営業支援に機械学習を用いようとした場合，どのよう な特徵量を選択するかは重要な問題である。本研究にお いては，営業マンへの聞き込み調査に基づいて採用する 初期特徴量を決定し，その後結果のフィードバックに基 づいて更なる特徵量の追加を行っている.さらに，ジニ 係数に基づいて, 重要な特徴量を抽出し精度向上を図っ ている.

特徵量の選択に際して, すべての変数から特徴量を抽 出することも考えられるが, すべての特徴量がデータベー ス化されているわけではなく，データを作成することも コストとなる，営業支援に活用しようとする場合，通常 業務のかたわらデータの収集や特徵量の選定などを行う こととなるため, 闇雲なデータ収集は通常業務に支障を きたしかねない，実際，今回のデータの一部は，内見時 にアンケートを新たに実施することで収集している。ア ンケートは実施コストがかかるため，実施コストが高い 場合は精度向上につながるとしても特徵量として利用で きない. 適用可否の判断として重要となるのは, 実施コ ストに対するリターンが十分に得られることである，本 事例においては，実施コストをできるだけ削減し，業務 に支障をきたさないように営業マンと十分に相談し，営 業マンが重要だと考える最小限の項目を選定している.

また，最終結果をフィードバックした後に $\mathrm{ABC}$ 店舗 に確認したところ，アンケートは申込み顧客推定精度向 上に大いに寄与しており，自動で申込み顧客を抽出する 本システムは有効と考えるため，アンケートの実施コス トは受け入れられるとのコメントが得られている.この ように, 従来の通常業務からは取得できない新たな特徵 量を使用する場合は，実施コストとリターンを検討する とともに，現場の理解が得られるようにその必要性や有 効性を丁寧に説明することが重要と考える.

従来，人間の勘と経験に基づいて行われていた業務を 情報技術によって支援しようとする場合は，情報技術あ りきで進めるのではなく，現場の暗黙知をコミュニケー ションなどにより形式知化し，特徵量として抽出するこ とが重要と考える. 例えば, 本研究では, 結果のフィー ドバックに基づいて開店意欲や地域ポテンシャルを抽出 することにより，より精度の高い申込及顧客推薦モデル を構築している.

\section{$5 \cdot 3$ アルゴリズムの選択}

特徵量の選択と同様に, どのようなアルゴリズムを選 択するかも重要な問題である。これまでの研究において は, データの性質に合わせて研究者がアルゴリズムを決 定したり, 複数のアルゴリズムを比較検討し一番予測精 度の高い手法を採用したりしている。

本研究の場合，3つのアルゴリズムの適合率を比較し， 予測精度の高いアルゴリズムを特定している. 表 2 の通 り，すべてのデータに対して RF が最も良い結果となっ たため, 申込み顧客推薦システムの構築には, RFが適し ていると考える.

ここで，アルゴリズム選択に当たっては，予測精度だ けでなくパラメータチューニングにかかるコストも検討 する必要がある. 各アルゴリズムにおけるパラメータは, 特徵量の数や種類が変わるごとに検証しなおす必要があ り, 複数のデータを比較する場合はそのつど調整するコ ストがかかる. 本研究ではモデル構築に Weka を用いて いるが，SVM を用いた場合，パラメータをデフォルト 設定のままとした場合, 今回示した予測精度よりも低く, 適合率が $0 \%$ になることもあった。 そのため, その都度 パラメータの調整を行っている.

今回は, 研究のためにすべてのアルゴリズムに対して, すべてのデータで検証しているが，実際の営業支援にお いては，期限内でのアルゴリズム選択が必要となる。そ のため, 基本となるデータに対してアルゴリズムの比較 を行い，使用するアルゴリズムを決定してから特徵量の 選定を行うなど, 効率よく作業を進める工夫が必要と考 える.

効率化の工夫は, 特徴量選択におけるコストに対して も同様に配慮する必要がある. 今回の実験では, SVMに おいて，データ 3 を用いた場合がもっとも高い精度になっ ており, 重要な特徵量に絞り込んだデータ（データ 5) が 適していないことが確認できる。これはアルゴリズム毎に 適した特徴量セットが異なることを示唆しており, SVM/ 決定木においてより精度のよい特徵量セットが存在する 可能性がある*1. しかしながら, 実際の営業支援などで の活用を考えた場合，すべてのアルゴリズムに対して最 適な特徵量セットを抽出し, かつ最適なパラメータ調整 をすることは非効率である，そのため，基本となるデー タセット（データ 1-4）に対して，アルゴリズムの比較 を行い，使用するアルゴリズムを決定（今回はRF）して から特徵量の細かい選定を行う（データ 5) という今回 の方法は，期間やコストに制限がある場合には有効であ ると考える。

\footnotetext{
*1 実際には, 今回提示した 5 つのデータ以外の複数の特徵量 セットに対して SVM を用いて精度向上を試みているが，40 \%を超える特徵量セットは見つけられていない.
} 


\section{4 申込顧客推薦システムの実装}

本節では, 申込顧客推薦システムの実装について述べ る。なお， $\mathrm{ABC}$ 店舗にて実運用しているシステムへの 実導入は，障害が発生した場合，業務を停止する可能性 もありリスクが高く, 研究の範囲外であると考える. 実 システムへの導入や UI の開発は, $\mathrm{ABC}$ 店舗のシステム 部門とサポート会社による開発が求められる. そのため, 本稿ではプロトタイプとして開発したシステムの構成を 示す.

本システムは, 図 3 のように特徵量データをまとめる データ処理機構, 顧客情報・物件情報・アクセスログを テーブルに持つデータベース，トレーニングデータに対 して RF を用いて作成した申込み顧客推薦モデルから構 成される。

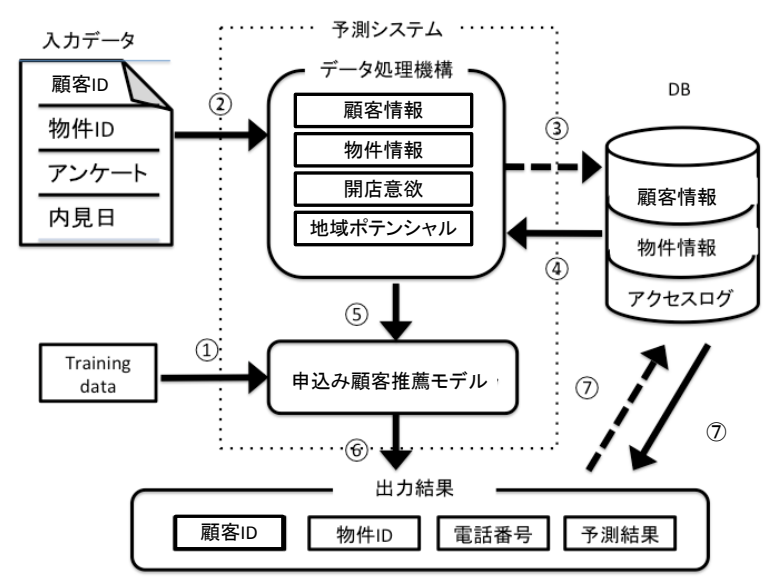

図 3 申込み顧客推薦システムの構成

（1）まず，事前に収集した training data から申込み顧 客分類モデルを構築する.

(2) 電話営業マンは内見した顧客リスト（顧客 ID, 物 件 ID，アンケート結果，内見日が記入されたもの) を csv 形式で読み込ませる.

（3）入力された顧客 ID, 物件 ID, 内見日から特徵量 として必要なデータを取得するためデータベースに クエリを送信する。

（4）クエリの結果（物件情報, 開店意欲, 地域ポテン シャル）をデータ処理機構に送信する.

（5）データ処理機構でまとめた特徴量を申込み顧客モ デルに送信する.

（6）申込み顧客モデルにより申込みの有無を推定する.

（7）推定結果に基づき出力された顧客 ID，物件 ID を データベースへ送信し, 氏名, 電話番号などの顧客 情報と住所, 賃料などの物件情報を提示し, 営業活 動支援を行う。

このようなシステムを実装することにより，営業の顧 客探索コストを削減するとともに, 新人営業などの経験 不足の営業マンであっても, 効率よく営業可能になると
考える.

\section{6. 結 論}

本研究では, 申込み見込顧客を営業マンに推薦するこ とで，営業マンの時間とコストを削減する申込み顧客推 薦モデルを提案した。モデル構築には, 顧客情報, 物件 情報の他に，フィードバックにより開店意欲，地域ポテ ンシャルの 2 つを新たな特徵量として抽出している.

評価実験の結果，RF をデータ 3 (顧客情報十物件情報) に用いた場合 $38.7 \%$ ，データ 4 （顧客情報十物件情報十 フィードバックに基づく特徵量）に用いた場合 $44.2 \%$, データ 5（重要な特徵量に絞り込んだデータ）に用いた 場合 49.2\%の適合率で，申込み顧客を推定できることが 確認できた。データ 3 とデータ 4 の比較により，新たな 特徵量（開店意欲，地域ポテンシャル）を抽出すること の重要性を確認している. また，データ 4 とデータ 5 の 比較により, 重要な特徵量の絞込みが精度向上に寄与す ることを確認している.

本研究が対処した問題は飲食店向け不動産の推薦とい う特異な問題であり，本研究によって抽出された特徵量 やアルゴリズムが他の営業支援に直ちに適用できるわけ ではない. 本研究の貢献は, 従業員の暗黙知を, フィード バックを含む聴き取り調査に基づいて抽出し，特徵量と して形式知化する手続きを実事例に基づいて示したこと である。また，その中において従業員とのコミュニケー ションの重要性および有効性, 通常業務への配慮, アル ゴリズムや特徵量セットの選定における手順を示したこ とである。これらは，機械学習を営業支援に活用しよう とする他の事例においても重要な観点であり, Web イン テリジェンスとインタラクション研究の発展に寄与する と考える.

今後はさらなる適合率向上を図るために，顧客が内見 に来訪している状態や営業マンの身体データをセンシン グすることで，申込み顧客の推定に有用な特徵量が抽出 できないか検討する.

\section{謝辞}

本研究の一部は科学研究費補助金 挑戦的萌芽研究 $15 \mathrm{~K} 12161$ の助成を受けたものである。また，株式会社 $\mathrm{ABC}$ 店舗 の方には, 本研究において, データ提供並びに貴重なご 意見を頂きました。心より御礼申し上げます.

\section{$\diamond$ 参 考 文 献 $\diamond$}

[Adomavicius 05] Adomavicius, G. and Tuzhilin, A.: Toward the Next Generation of Recomender Systems: A Survey of the State-ofthe-Art and Possible Extensions, IEEE Trans. Knowledge and Data Engineering,Vol.17, No.6, pp.734-749(2005)

[Breiman 01] Breiman, L.: Random Forests, Machine Learning, Vol. 45, pp.5-32 (Oct.2001) 
[Cristianini 00] Cristianini, N. and Shawe-Talor, J.: An Introduction to Support Vector Machines and other Kernel-based Learning Methods, Cambridge University Press (2000).(大北剛訳『サポートベク ターマシン入門』, 共立出版 (2005)

[Fu 14] Fu, Y., Ge, Y., Zheng, Y., Yao, Z., Liu, Y., Xiong, H., and Yuan, N. J.: Sparse Real Estate Ranking with Online User Reviews and Offline Moving Behaviors, in 2014 IEEE International Conference on Data Mining (ICDM), pp.120-129, IEEE (2014)

[土方 04] 土方嘉徳: 情報推薦・情報フィルタリングのためのユー ザープロファイリング技術, 人工知能学会誌, Vol. 19, No. 3,pp.365372 (2004)

[J.Ben 01] J.Ben Schafer, J. A. Konstan, and Riedl, J.: E-Commerce Recommendation Applications, Data Mining and Knowledge Discovery,Vol.5, pp.115-153 (2001)

[神嶌 06] 神嶌敏弘 : 推薦システム-情報過多時代をのりきる, 情 報の科学と技術, Vol. 56, No. 10, pp.452-457 (2006)

[神嶌 08] 神嶌敏弘 : 推薦システムのアルゴリズム (2), 人工知能 学会誌, Vol.23, No.1, pp.89-103(2008)

[Mooney 99] Mooney, R.J. and Roy, L.: Content-Based Book Recomending Using Learning for Text Categorization, Proc. ACM SIGIR 99 Workshop Recommender Systems: Algorithms and Evaluation(1999)

[Pazzani 96] Pazzani, M., Muramatsu, J. and Billsus, D.: Syskill \& Webert: Identifying interesting web sites, Proc. 13th National Conf. on Artitificial Intelligence, pp.54-61(1996)

[Quinlan 96] Quinlan, J. R.: Improved Use of Continuous Attributes in C4.5, Journal of Artificial Intelligence Research, Vol.4, pp.7790(1996)

[Resnick 99] Resnick, P., Iacovou, N., Suchak, M., Bergstorm, P. and Riedl,J.: GroupLens: an open architecuture for collabolative filtering of netnews, Proc. ACM Conf. on Computre Supported Cooperative Work, pp.175-186(1994)

[Resnick 94] Resnick, P. and Varian, H.: Recommender systems, Comm. ACM, Vol.40, No.3, pp.56-58(1997)

[Saeideh 14] Saeideh Bakhsi, P. K. and Gilbert, E.: Demographics, Weather and Online Reviews: A Study of Restaurant Recommendations, Proc. 23rd International Conference on World Wide Web, pp.443-454 (2014)

[Wu 09] Wu, C.-H., Li, C.-H., Fang, I.-C., Hsu, C.-C., Lin,W.-T., and Wu, C.-H.: Hybrid Genetic-Based Support Vector Regression with Feng Shui Theory for Appraising Real Estate Price, First Asian Conference on Intelligent Information and Database Systems (ACIIDS 2009), pp.295-300IEEE (2009)

[Yiqing 15] Yiqing, H., Fangzhou, Z., Mingxuan, Y., Ke, D., Yanhua,L., Bing, N., Wenyuan, D., Qiang, Y., and Jia, Z.: Telco Churn Prediction with Big Data, Expert Systems with Applications, pp.607618 (2015)

[Weka 14] Weka 3:Data Mining Software in Java, available from $\langle$ http://www.cs.waikato.ac.nz/ml/weka/〉 (accessed 2014-12-01).

〔担当委員 : 奥 健太〕

2016 年 5 月 11 日 受理

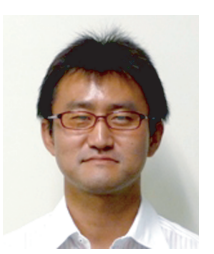

\section{諏訪 博彦(正会員)}

1998 年群馬大学社会情報学部卒業. 2006 年電気通信大学 大学院情報システム学研究科博士後期課程修了. 博士（学 術). 2014 年 10 月より奈良先端科学技術大学院大学助教。 社会情報システム学に関する研究に従事.

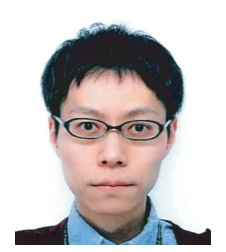

\section{小川 祐樹(正会員)}

2006 年大分大学工学部卒業. 2011 年電気通信大学大学院 情報システム学研究科博士課程修了, 博士 (工学) . 現在, 立命館大学情報理工学部助教. 社会シミュレーション, ソー シャルメディアにおける意見形成などの研究に従事.

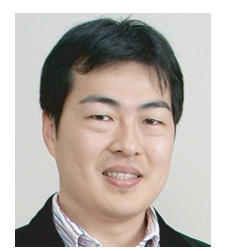

荒川

2001 年慶應義塾大学理工学部卒業. 2006 年同大学院理工 学研究科博士課程修了. 博士 (工学). 2013 年より奈良先 端科学技術大学院大学情報科学研究科准教授.ネットワー クアプリケーション, ソーシャルデータマイニングに関す る研究に従事.

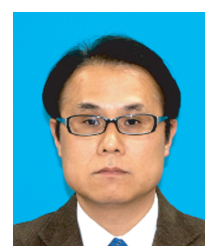

安本 慶一

1991 年大阪大学基礎工学部情報工学科卒業. 1995 年同大 学大学院博士後期課程退学. 2011 年より奈良先端科学技 術大学院大学情報科学研究科教授. ユビキタスコンピュー ティングに関する研究に従事.

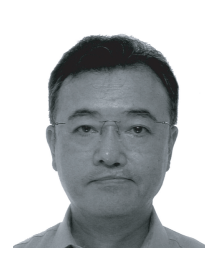

太田 敏澄

元電気通信大学大学院情報システム学研究科教授. 2016 年 逝去. 1970 年東京工業大学経営工学科卒業, 1972 年同大 学院理工学研究科修士課程修了. 1977 年工学博士.『社会 情報システム学序説』『社会情報学のダイナミズム』や多 くの論文を通じて，社会情報システム学の発展に尽力した。 元日本社会情報学会会長. 社会情報システム学研究会初代 代表および名誉代表.

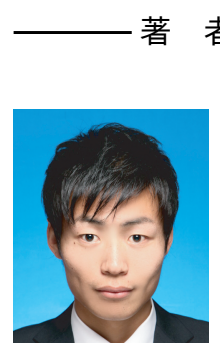

1990 年生. 2014 年関西学院大学理工学部物理学科卒業. 2016 年奈良先端科学技術大学院大学情報科学研究科博士 前期課程修了．現在，NTT コミュニケーションズ株式会 社に勤務。機械学習に関する研究に従事。 